\title{
Prawo naturalne jako hermeneutyczna podstawa etyki uniwersalnej
}

\section{NATURAL LAW AS THE HERMENEUTICAL BASIS OF THE UNIVERSAL ETHICS}

Rationalism of human nature demands to know the moral foundations and legitimacy made by human decisions and actions. This norm directs to the human nature, since a man first of all he wants - and should - be a man what means to pursue contained in its nature objectives and capabilities. This fact calls for the recognition of human nature, which is the ontological foundation of ethical norms of human action. This problem becomes more timely in the context of the development of modern civilization and cultural, scientific and technological progress and the growth of the needs and possibilities of their fulfillment. The consequence of these changes is deepening differentiation of human action evaluation and justification of ethical standards. This condition demands intensification of their search for the basics of universal ethical standards and guidance, motivation of its obliging nature of the universal dimension. Such a foundation of ethical standards of a general nature is a natural law anchored in the personal nature of the human beings that connects all people and sets them to a common norm of conduct. In this analytical reflection we will focus on two dimensions of the title issues: 1 . The essence of the natural law obliging its power and attitude to the statute law; 2 . The natural law as the standard valuation of human action and its deformations.

Key words: nature, natural law, the statute law, civilization and cultural transformation, ethical evaluation, moral obligations, moral deformation, moral responsibility. 


\section{Wstęp}

Racjonalny charakter ludzkiej natury objawia się w aktach rozumu stawiającego pytania dotyczące fundamentów egzystencji człowieka: Hermeneutyka skąd pochodzę, kim jestem i dokąd zmierzam. Racjonalna odpowiedź na te pytania stanowi uzasadnienie wszelkich ludzkich działań, które stają się sensowne i celowościowe. W wymiarze działaniowym pytania te koncentrują się wokół natury ludzkiej, której poznanie stoi u podstaw zasadności podejmowanych decyzji i działań. Człowiek bowiem przede wszystkim chce - i powinien - być człowiekiem, czyli realizować zawarte w swej naturze cele i możliwości. Wyraża się to w powszechnie zrozumiałych i zasadnych normach: „Bądź człowiekiem”, „Żyj jak człowiek”. Realizacja tych zasad domaga się rozpoznania natury człowieka, która stanowi fundamentalną normę etyczną o charakterze powszechnym. Wszyscy bowiem ludzie - istoty posiadające tę samą osobową naturę - winni kierować się jednym prawem moralnym. Stąd też, prawo naturalne stanowi obiektywny fundament wszelkich norm ludzkiego działania oraz hermeneutyczną podstawę etyki uniwersalnej.

Problem ten staje się dzisiaj coraz bardziej aktualny w kontekście szybkiego i różnorodnego rozwoju ludzkiej cywilizacji, postępu naukowo-technicznego, mnożenia się form ludzkich potrzeb i możliwości ich spełniania. Z tym wiąże się rozbicie społeczno-kulturowe, defraudacja ludzkiej wolności pojmowanej jako do-wolność, co przejawia się także mnożeniem się form przemocy i zagrożeń ludzkiej tożsamości i egzystencji. Konsekwencją takiego rozwoju jest pogłębiające się zróżnicowanie myślenia i ustalania norm realizacji ludzkich potrzeb. Wielu ludzi przyjmuje jako fundamentalną zasadę swojej etyki egoistyczny indywidualizm, bez liczenia się z jakąkolwiek normą powszechną. Stan ten domaga się intensywnych poszukiwań podstaw uniwersalnej normy etycznej oraz wskazania motywacji jej zobowiązującego charakteru. Takim fundamentem wszelkich norm etycznych jest prawo naturalne, zakotwiczone w osobowej naturze człowieka, która łączy wszystkich ludzi i wyznacza im ten sam sposób postępowania. W niniejszej analitycznej refleksji na ten temat chcemy skupić się na dwóch wymiarach tytułowego zagadnienia: 1. Istota prawa naturalnego, jego moc zobowiązująca i stosunek do prawa stanowionego; 2. Prawo naturalne jako norma wartościowania ludzkiego działania i jej deformacje. 


\section{Istota prawa naturalnego, jego moc zobowiązująca i stosunek do prawa stanowionego}

Naczelną potrzebą ludzkiej egzystencji jest rozpoznanie fundamentalnych zasad kierujących decydowaniem i postępowaniem człowieka. Hermeneutyka Ten imperatyw koncentruje się na prawie naturalnym (łac. ius naturale), stanowiącym porządek prawny - różny od prawa stanowionego przez człowieka - którego podstawą jest sama natura rzeczywistości świata. Zależnie od koncepcji światopoglądowych, natura jest pojmowana jako wola Boga lub jako nakaz rozumu, bądź też wrodzonego poczucia sprawiedliwości (koncepcja psychologiczna). Zakotwiczenie w naturze jako rzeczywistości stałej i powszechnej, jest podstawą uznania prawa naturalnego jako wspólnego wszystkim kulturom, łączącego wszystkich ludzi, stanowiącego wspólne zasady postępowania. Jest ono trwałe i niezmienne, niezależnie od przemian historyczno-kulturowych oraz społeczno-moralnych. Jako oparte na ludzkiej naturze, prawo naturalne nie jest człowiekowi nadawane; człowiek otrzymuje je w momencie poczęcia - uzyskania osobowej natury. Prawo to nie może też być mu odebrane, gdyż nikt i nic nie może pozbawić człowieka jego natury; sam człowiek też nie może zrezygnować z tego prawa, gdyż nie może pozbawić siebie ludzkiej natury - bycia człowiekiem. Prawo naturalne określa podstawowe uprawnienia i obowiązki osoby ludzkiej, broni godności człowieka, zapewniając mu prawo do życia i jego godnego utrzymania, przede wszystkim prawo samoposiadania, prawo do podejmowania decyzji, prawo posiadania własności, prawo do pracy o jej owoców ${ }^{1}$.

Prawo naturalne jako fundamentalna i powszechna norma ludzkiego działania stanowi stały i nieprzerwany przedmiot ludzkich zainteresowań badawczych. Początki tych poszukiwań znajdujemy w filozoficznej myśli starożytnych sofistów (VI-V w. p.n.e.). Istotną rolę odgrywało tu rozróżnienie między naturą ( Przez prawo natury rozumiano prawo oparte na wspólnej wszystkim ludziom naturze, która łączy ludzi i sprawia, że wszyscy są równi. Przeciwstawieniem prawa natury jest prawo ludzkie - pozytywne (ius positivum), które przeciwstawia się tej równości, dzieli ludzi i przeciwstawia ich sobie. Prawo natury jest wieczne i niezmienne, natomiast prawa ludzkie są przygodne, oparte na społecznej konwencji, którą

Zob.Międzynarodowa Komisja Teologiczna, W poszukiwaniu etyki uniwersalnej: Nowe spojrzenie na prawo naturalne, tłum. R. Kiełtyka, Warszawa 2010, nr-1-11; M. A. Krąpiec, Człowiek i prawo naturalne, Lublin 1999, s. 177-180; S. Kirste, Der Beitrag des Rechts zum kulturellen Gedächtnis, „ARSP”, 2008, vol. 94, z. 1, s. 47-69. 
można zmieniać i dowolnie kształtować. Jedność ludzkiej natury stanowi podstawę kosmopolityzmu ukazującego równość wszystkich ludzi, będących sobie braćmi, niezależnie od społeczności (polis), języka czy kultury².

Hermeneutyka Pogłębienie tych poszukiwań znajdujemy w myśli największego filozofa starożytności - Arystotelesa. Naturę człowieka postrzega on w kontekście filozofii teleologicznej: „Natura bowiem (...),nie czyni nic bez celu"' . Ludzki rozum mając na względzie naturalne cele, prowadzi człowieka do tego, co jest mu dobre, co godzi się z jego rozumną naturą. Naturalnym zaś celem ludzkiej egzystencji jest szczęście (ópєt门́, arete), które można osiągnąć żyjąc zgodnie z prawami natury. Stąd też Arystotelesowska koncepcja prawa natury ma charakter ściśle etyczny; prawo naturalne służy eudajmonii, a jego naruszenie pozbawia człowieka szczęścia. Treści prawa naturalnego wynikają z naturalnych uzdolnień człowieka do rozróżniania dobra i zła, sprawiedliwości i niesprawiedliwości, co przyjmuje postać wspólnych wszystkim ludziom ocen moralnych. Społeczny charakter ludzkiej natury sprawia, że także prawo stanowione przez państwo znajduje swe oparcie w ludzkiej naturze - ma służyć osiąganiu szczęścia. Fundamentem prawa stanowionego jest prawo naturalne, choć między nimi zachodzi istotna różnica. Prawo naturalne jest dane wszystkim ludziom jako istotom rozumnym w sposób bezpośredni, prawo zaś stanowione jest spisane i wymaga intelektualnego poznania. Prawo stanowione nie jest też prawem powszechnym, lecz obowiązuje tylko obywateli konkretnej społeczności - polis, i w konkretnym czasie. Oba rodzaje praw stanowią niezbędny normatyw realizacji naturalnych celów ludzkich działań, gdyż ich przestrzeganie zapewnia sprawiedliwość naturalną i stanowionąa

Pogłębienie starożytnej koncepcji prawa naturalnego dokonane zostało w myśli chrześcijańskiej. Znacząca zmiana w tej interpretacji związana jest z pojmowaniem osobowego Boga jako Stwórcy i Zbawiciela świata, a tym samym źródła wszelkich norm prawno-moralnych. U początków chrześcijaństwa szczególne znaczenie posiada myśl św. Augustyna (353-430), który prezentuje woluntarystyczną filozofię

2 Zob. G. Reale, Historia filozofii starożytnej, t. 1, Lublin 2008, s. 280-282; R. Tokarczyk, Klasycy praw natury, Lublin 1988, s. 20-38.

3 Arystoteles, Polityka, 1253 a. Zob. J. Bocheński, Zarys historiifilozofii, Kraków 1993, s. 56-68.

4 Por. Arystoteles, Politykaz dodaniem pseudo-arystotelesowskiej Ekonomii, Warszawa 1964, s. 1253-1255 a; R. Tokarczyk, Klasycy praw natury, op. cit., s. 39-60. Zob. także: E. Schockenhoff, Naturrecht und Menschenwürde. Universale Ethik in einer geschichtlichen Welt, Mainz 1996. 
prawa, stanowiącą zwornik między klasyczną myślą starożytności a chrześcijańską myślą średniowiecza ${ }^{5}$. Idąc za myślą Platona i stoików, św. Augustyn wyróżnia trzy rodzaje praw: prawo wieczne (lex aeterna), prawo naturalne (lex naturalis) i prawo stanowione (lex temporalis). Źródłem wszelkich norm jest prawo wieczne, którego treścią jest przenikający całą naturę świata Boski porządek, będący wyrazem rozumu i woli Boga. Wyrazem zaś uczestnictwa tego Boskiego porządku - lex aeterna - w rozumnej naturze człowieka jest prawo naturalne, które jest normą racjonalną (lex rationis) i moralną (lex naturalis moralis). Prawo naturalne stanowi subiektywną postać porządku obiektywnego i jest możliwe do poznania wszystkim ludziom jako istotom zdolnym do intelektualnej refleksji. Prawo stanowione przez ludzi tylko wtedy może być uznane za sprawiedliwą normę zobowiązującą, gdy jest wyprowadzone z prawa naturalnego, a w konsekwencji z wiecznego - Bożego ${ }^{6}$.

Woluntarystyczna koncepcja prawa św. Augustyna została przekształcona przez św. Tomasza z Akwinu (1225-1274), który podkreśla, że decyzję woli poprzedza akt rozumu (primum principium), będący regułą i miarą wszelkich ludzkich czynów. Akt rozumu pozwala człowiekowi rozróżnić, że źródłową podstawą wszelkich praw jest prawo wieczne (lex aeterna) istniejące samo przez się (per se). Natomiast „prawo naturalne nie jest niczym innym, jak uczestnictwem prawa wiecznego w stworzeniu rozumnym" ". Prawo naturalne jest wyrazem uczestnictwa (per participationem) prawa wiecznego w naturze człowieka. Kategorią definiująca prawo naturalne jest „prawo wieczne”, które - według św. Tomasza - ,jest zamysłem Bożej mądrości, o ile ukierunkowuje wszystkie akty i poruszenia"». Owo ukierunkowanie „wszystkich aktów i poruszeń" dotyczy wszystkich stworzeń, a pochodzi ono od celu ich egzystencji. Jest to związane z fundamentalnym

5 Por. W. Kornatowski, Społeczno-polityczna myślśw.Augustyna, Warszawa 1965, s. 277-281; zob. także: A.-H. Chroust, The Fundamental Ideas in St. Augustine Philosophy of Law, "The American Journal of Jurisprudence", 1973, vol. 18.

$6 \quad$ Por. R. Tokarczuk, Klasycy praw natury, op. cit., s. 109-123; zob. także: H. Olszewski, M. Zmierczak, Historia doktryn politycznych i prawnych, Poznań 1993, s. $46-49$.

7 S. Thomae Aquinatis, Summa theologiae, I-II, q. 91,a. 2, resp.: ,[...] lex naturalis nihil aliud quam partiocipatio legis aeternae in rationali creatura".

8 S. Thomae Aquinatis, Summa theologiae, I-II, q. 93, a. 1, resp.: „lex aeterana (...) ratio divinae sapientiae; secundum quod est directiva omnium actuum et motionum". 
pojmowaniem prawa, które „nie jest niczym innym, jak racją działania, wszelka zaś racja działania zawarta jest w celu"9.

Prawo naturalne jest tu rozumiane jako uczestnictwo człowieka w prawie wiecznym, czyli w owym ,zamyśle” na cel działania poszczeHermeneutyka gólnego stworzenia. Jako „uczestnictwo” w Bożym zamyśle, prawo naturalne jest możliwe do poznania człowiekowi i pozwala mu odróżnić dobro od zła. Wymaga to jednak czynnego zaangażowania w rozpoznawanie oraz przestrzeganie prawa wiecznego. Wyrazem owego wysiłku poznawczego jest prawo pozytywne - ludzkie (lex positiva, lex humana), będące ludzkim „uzupełnieniem” prawa naturalnego. Ma ono charakter zobowiązujący dopóty, dopóki nie staje w sprzeczności z prawem wiecznym, które człowiek rozpoznaje w Bożym Objawieniu ${ }^{10}$.

W czasach nowożytnych w pełni świecką koncepcję prawa naturalnego skonstruował holenderski myśliciel Huig de Grot (1585-1645), zwany Grocjusz. W jego koncepcji prawo naturalne jest nakazem prawego rozumu (dictatus rectes rationis). Moralna wartość ludzkich działań zależna jest od zgodności z rozumną naturą człowieka. Rozum bowiem jest narzędziem rozpoznawania podstawowych zasad relacji międzyludzkich, których charakter zobowiązujący równy jest mocy obowiązywalności aksjomatów matematycznych: „prawo naturalne jest do tego stopnia niezmienne, że sam Bóg nie może go zmienić [...], nawet Bóg nie może sprawić, by dwa razy dwa nie było cztery, ani też, by to, co w sobie jest złe, nie było takim"11. Jako nakaz rozumu, prawo naturalne zobowiązuje człowieka do postępowania zgodnego $\mathrm{z}$ rozumną naturą, pozostając jedynie pod sankcją moralną - wyrzutami sumienia. Tak pojmowane prawo naturalne obowiązuje nawet przy założeniu, że Boga nie ma (etiamsi daremus non esse Deum) lub że nie troszczy się On o ludzkie sprawy. Grocjusz uważany jest za autora nowożytnej koncepcji praw podmiotowych, który odszedł od idei rozumu Boskiego na rzecz tworzącej prawo idei rozumu ludzkiego. $\mathrm{W}$ jego rozumieniu prawo naturalne jest podstawą wszelkich praw,

$9 \quad$ S. Thomae Aquinatis, Summa contra Gentiles, III, 114, n. 5: „[...] lex nihil est sit quam ratio operis; cuiuslinet autem operis ratio a fine sumitur[...]”. Zob. M. Piechowiak, Prawo naturalne a prawa człowieka, [w:] A. Maryniarczyk, K. Stępień, P. Gądek (red.), Substancja, Natura, Prawo naturalne, Lublin 2006 , s. 396-398.

10 Zob. Międzynarodowa Komisja Teologiczna, W poszukiwaniu etyki uniwersalnej..., op. cit., nr 60-68; M. A. Krąpiec, Człowiek i prawo naturalne, op. cit., s. 189-207.

11 H. Grocjusz, Trzy księgi o prawie wojny i pokoju, wktórych znajdują wyjaśnienie prawo natury i prawo narodów, tłum. R. Bierzanek, Warszawa 1957, s. 93. 
reguluje relacje zarówno między pojedynczymi osobami, jak też między narodami ${ }^{12}$.

Przywołane tu fundamentalne koncepcje rozumienia prawa naturalnego w jego wymiarze normatywnym ukazuje je jako fundament moralności i porządku prawno-społecznego. Prawo naturalne jawi się jako moralna podstawa ludzkiego postępowania i ostatecznego jego uzasadnienia. Historyczny rozwój i zmienność pojmowania natury wyrażał się w zróżnicowanym rozumieniu koncepcji prawa naturalnego: od fundamentu moralno-prawnego w starożytności i średniowieczu, do negatywnego odniesienia w stanowisku historyzmu i pozytywizmu XIX i XX wieku. Jednak nawet najbardziej radykalne negacje prawa naturalnego nie przekreśliły jego istotnego znaczenia w najbardziej krytycznych momentach życia ludzkich jednostek i społeczności. W takich bowiem sytuacjach człowiek doświadcza, że pozytywne sformułowanie prawa (prawo ludzkie) jest niewystarczające w stosunku do życiowych problemów podejmowania decyzji, które naruszają dane prawo pozytywne. Powszechnie znanym wyrazem i przykładem rozumienia zobowiązującej mocy prawa naturalnego był Proces Norymberski i wyroki Międzynarodowego Trybunału, który odrzucił legalność prawa państwowego dopuszczającego zabijanie ludzi, uznając moc wiążącą ponadnarodowego i ponadpaństwowego - wiążącego w sumieniu - prawa naturalnego, zakazującego realizację zła nawet w imię interesów państwa czy narodu. „Człowiek bowiem zawsze pozostaje człowiekiem, który jest zdolny do czynienia i rozumienia naturalnego układu rzeczy, ludzkiego dobra i zła spełnianego przez człowieka i w stosunku do drugiego człowieka. Właśnie owa zdolność rozumienia dobra i zła tudzież realizowanie odczytanego dobra w swoim postępowaniu wiąże się koniecznościowo z samym rozumieniem obecności naturalnego prawa wewnątrz człowieka i wśród ludzi" ${ }^{13}$.

\section{Prawo naturalne jako norma wartościowania ludzkiego działania i jej deformacje}

Analityczna refleksja filozoficzno-teologiczna przekonuje, że prawo naturalne stanowi fundamentalną zasadę funkcjonowania osoby ludzkiej. Fakt ten uświadamia konieczność kierowania się tą normą

12 Por. H. Olszewski, M. Zmierczak, Historia doktryn politycznych i prawnych, Poznań 1994, s. 125-127; R. Tokarczyk, Klasycy praw natury, op. cit., s. 171-188.

13 M. A. Krąpiec, Człowiek i prawo naturalne, op. cit., s. 8. Zob. Ph. d'Iribarne, Conversion et résistance des cultures, „Christus. Accompagner l'homme en quête de Dieu", 2011, nr 229, s. 95-104. 
we wszelkich decyzjach człowieka oraz ocenach jego działania. Wartość bowiem ludzkich czynów zakotwiczona jest w naturze osoby jako podmiotu oraz adresata tychże działań. Każdy „ludzki” czyn bierze początek w osobowej naturze człowieka i jego wartość winna być Hermeneutyka zgodna z normą zawartą w tejże naturze. To prowadzi do wniosku, że natura posiada charakter normatywny,

zwłaszcza gdy jest postrzegana jako wewnętrzna zasada ruchu, która prowadzi podmiot w kierunku spełnienia. Pojęcie natury nie jest statycznym motywem, ale określa dynamiczną zasadę rzeczywistego rozwoju jednolitego podmiotu i jego poszczególnych działań ${ }^{14}$.

Potwierdzeniem zasadności tego przekonania jest uświadomienie istoty działania natury osoby ludzkiej. Poznając działanie natury bytu osobowego, doświadczamy ich trwałości oraz autonomiczności w porządku aktywnego istnienia. Ta aktywność bytu osobowego charakteryzuje się relacyjną, wyrażającą się w otwartości na drugą osobę i utrzymywaniu związków przyczynowych. „W porządku duchowym osoby tworzą intersubiektywne relacje. Natury kształtują w ten sposób sieć, i w ostatecznym porządku, to oznacza jednolity szereg w odniesieniu do zasady" ${ }^{15}$. Uświadomienie tego faktu pozwala rozpoznać związek i komplementarną zależność między ludzką naturą i osobą. Faktem jest, że osoba i natura są dwoma pojęciami, które nie sprzeciwiają się sobie, lecz wzajemnie siebie tłumaczą i uzupełniają. Osoba ludzka jest jedyną w swym rodzaju realizacją metafizycznej ludzkiej natury, poprzez którą w akcie wolnego wyboru dokonuje ona działań, będących odpowiedzią na życiowe powołanie bytu osobowego.

Natura stwarza rzeczywiście warunki korzystania z wolności i wskazuje kierunek do wyborów, które musi spełnić osoba. W badaniu zrozumiałości swojej natury osoba odkrywa również drogi swojej realizacji ${ }^{16}$.

Prawda ta posiada charakter normatywny: człowiek w swoim działaniu oraz w jego ocenie winien kierować się prawem naturalnym. Stanowi ono weryfikacyjną normę moralnej zasadności podejmowanych decyzji oraz wartościowania ludzkich czynów.

We współczesnym świecie nasila się tendencja odchodzenia od tej zasady, nadająca absolutyzacyjny charakter ludzkiej wolności oraz wpływ czynników zewnętrznych. Szczególnie niebezpieczne jest to

14 Międzynarodowa Komisja Teologiczna, W poszukiwaniu etyki uniwersalnej..., op. cit., $\mathrm{nr} 64$.

$15 \quad$ Ibidem, $\mathrm{nr} 65$.

16 Ibidem, nr 68. Zob. K. B. Schnebel, Individuelles und Kollektiv ausgeübtes Menschenrecht als Selbstbestimmungsrecht, „ARSP”, 2008, vol. 94, z. 1, s. 26-46. 
w zakresie wartościowania ludzkiego życia oraz kwalifikacji osobowych postaw w ich wymiarze etycznym. Przykładem tego jest sztuczna prokreacja, będąca deformacją osobowej godności człowieka. U podstaw zasadności sztucznej prokreacji sytuuje się kreowana ideologia „człowieka ponowoczesnego". Opiera się ona na zafałszowanej teorii człowieczeństwa określanej mianem biologizm. Jest to kierunek myśli i postaw, preferujący wyłącznie biologiczny punkt widzenia człowieka, degradujący osobową naturę ludzką do jednego z żywych organizmów, stanowiących wyłącznie biologiczny element przyrody. Z tym wiąże się psychoanalityczna koncepcja człowieka określanego jako „fakt ludzki”, ujmowany w niektórych ważnych aspektach ,ja” neurotycznego. Do tego dochodzi materialistyczno-marksistowska koncepcja osoby ludzkiej, postrzeganej w kategorii bytu będącego w „alienacji”, w swej istocie zależny od społeczeństwa, które ma prawo zupełnego decydowania o życiu konkretnej jednostki ludzkiej ${ }^{17}$.

W przypadku sztucznej prokreacji podstawową formą destrukcji osoby ludzkiej i prawa naturalnego jest brak uznania i uszanowania osobowej natury człowieka w jego prawie do życia i integralności cielesnej od poczęcia do naturalnej śmierci.

Istota ludzka powinna być szanowana i traktowana jako osoba od chwili swojego poczęcia i dlatego od tej samej chwili należy uznać jej prawa osoby, a wśród nich nade wszystko nienaruszalne prawo każdej niewinnej istoty ludzkiej do życia ${ }^{18}$.

W procesie sztucznej prokreacji pomija się lub neguję tę prawdę, która znajduje swe potwierdzenie w wynikach badań dotyczących ludzkiego embrionu, wykluczających stopniowanie kwalifikacji ontologicznej ludzkiej natury. Człowiek od poczęcia posiada pełną kwalifikację antropologiczną i etyczną właściwą osobie ludzkiej. Niemożliwość bezpośredniego doświadczenia duchowej duszy w embrionie ludzkim, nie oznacza zmiany kategorialnej natury człowieka na tym etapie rozwoju. Identyfikacja osób aktywnych umysłowo nie dokonuje się bowiem wyłącznie świadomie czy dyskursywnie - in re (jak to założył J. Locke), lecz także podświadomie - in potentia, stanowiąc spotkanie osób.

17 Por. M. Wallis, Koncepcje biologicznewhumanistyce,[w:]Fragmenty filozoficzne, III. Księga Pamiatkowa ku czci Profesora Tadeusza Kotarbinskiego w 80. rocznice urodzin, Warszawa 1967, s. 307-330; T. Ślipko, Pojęcie człowieka w świetle wspótczesnej filozoficznej antropologii marksistowskiej w Polsce, „Zeszyty Naukowe KUL”, 1967, nr 2, s. 3-16. Z. Bauman, Etyka ponowoczesna, Warszawa 1996, s. 51-84.

18 Kongregacja Nauki Wiary, Instrukcja Dignitas personae, Rzym 2008, nr 4. Por. J. Zabielski, Odpowiedzialność za życie, Białystok 2007, s. 72-84. 
Hermeneutyka

Spotykając drugą osobę, spotykam byt o określonej strukturze, na tyle innej, że rezultaty tego spotkania są inne niż w przypadku bytów nieosobowych. Ten specyficzny rezultat nazywamy tu relacjami osobowymi. Stanowią one skutek zetknięcia się z przejawami aktu istnienia bytu osobowego ${ }^{19}$.

Brak zachowania norm prawa naturalnego wyraża się w niszczeniu życia w stanie embrionalnym oraz w wyłącznie instrumentalnym traktowaniu embrionów. Stosowane dzisiaj „,metody zapłodnienia in vitro są akceptowane, ponieważ zakłada się, że embrion nie zasługuje na pełny szacunek z powodu tego, że staje się rywalem wobec pragnienia, które trzeba zaspokoić" ${ }^{20}$. Wyraża się to także w wykorzystywaniu embrionów jako „materiału biologicznego”. Stąd też „kriokonserwację owocytów w celu sztucznego przekazywania życia należy uznać za moralnie nie do przyjęcia"21.

Niemoralność tych działań wyraża się w traktowaniu embrionu ludzkiego jako „materiału laboratoryjnego”. Jest to działaniem pro-aborcyjnym, wyrażającym mentalność eugeniczną, która rości sobie pretensję do wartościowania ludzkiego życia według kryteriów tzw. normalności, co stanowi uprawnienie do aborcji i eutanazji. W rzeczywistości „dochodzi do zafałszowania i zmiany również samego pojęcia godności ludzkiej. Godność przynależy w równym stopniu każdej poszczególnej istocie ludzkiej i nie jest zależna od planów rodzicielskich, pochodzenia społecznego, formacji kulturalnej i stanu rozwoju fizycznego"22. Odejście od tej normy prawa naturalnego prowadzi do odmawiania prawa do życia płodowi ludzkiemu, jeżeli zaistnieją „uzasadnione racje”. Daje to podstawę stanowienia prawa aborcji i eutanazji, będącym w sprzeczności z naturalnym prawem człowieka do życia, którego człowiek sam sobie nie nadał i nie może z niego zrezygnować ani pozbawić go drugiego człowieka. Zwolennicy aborcji i eutanazji nie liczą się z danymi nauki, która jednoznacznie stwierdza, że osoba ludzka nie jest rzeczą,

$19 \quad$ K. Wojcieszek, Relacyjna identyfikacja człowieczeństwa embrionu, „Colloquia Communia”, 2005, nr 1-2, s. 265. Por. J. Zabielski, Sztuczna prokreacja jako destrukcja osobowej godności człowieka, [w:] T. Reroń (red.), Świętość ludzkiego życia. Wokót Instrukcji „Dignitas personae”, Wrocław 2009, s. 225-242. Kongregacja Nauki Wiary, Instrukcja Dignitas personae, op. cit., nr 14.

Ibidem,nr 20. Zob. B. Chyrowicz, Bezcenna, ,informacja”. Uwagi na temat normatywnego statusu genomu ludzkiego, [w:] idem (red.), Granice ingerencji $w$ naturę, Lublin 2001, s. 31-52.

Instrukcja Dignitas personae, op. cit., nr 22. Por. J. Zabielski, Fertilisierung In Vitro. Die Sicht der Kirche, [w:] A. Laun, A. Marcol (red.), Ethisch relevante Techniken der Biologen, Opole 2003, s. 25-31. 
ani materiałem, ani tworem. [...] Natura ludzka jest obecna wraz ze swymi potencjalnościami, i oznacza to coś zupełnie innego niż być tylko potencjalnie człowiekiem; przecież nie można być bardziej lub mniej rzeczą, bardziej lub mniej osobą. Szacunek dla niej nie ma więc charakteru dowolności ${ }^{23}$.

Innym niezwykle drastyczny deformowaniem prawa naturalnego we współczesnym świecie jest przejaw współczesnej rewolucji antropologicznej w postaci ideologii tzw. gender. Jest to postać totalitaryzmu kulturowo-moralnego, która niszczy podstawy ludzkiej egzystencji oraz samego człowieka. W tzw. Zasadach z Yogyakarty totalitarny program ideologii gender zdefiniowany jest następująco:

Jako identyfikację płciową rozumie się głęboko odczuwane wewnętrzne i osobiste poczucie przynależności do określonej płci, która to płeć odpowiada lub nie odpowiada tej płci, którą miał dany człowiek przy urodzeniu ${ }^{24}$.

Mamy tu do czynienia z kuriozalną koncepcją rozumienia ludzkiej natury w jej wymiarze płciowym. Wyrazem zaprzeczenia natury (contra naturam) jest tu pojmowanie płci „wewnętrznego osobistego odczucia”, a nie ugruntowanie jej w cechach biologicznych, hormonalnych, neuronalnych, społecznych i psychicznych, jakie otrzymał człowiek w momencie poczęcia i urodzenia. Mamy tu do czynienia z próbą obalenia tożsamości ludzkiej natury, co znajduje już dzisiaj wyraz w stanowionym prawie wielu państw, np. Niemiecka Rada Etyki, obok płci męskiej i żeńskiej, wprowadzenie trzeciej kategorii - „inna płeć”25. Tego rodzaju myślenie i działanie jest sprzeczne z powszechnym rozumieniem ludzkiej natury oraz z jej planem zawartym w woli Boga

J.-M. Varaut, Możliwe, lecz zakazane. O powinności prawa, tłum. S. Szwabski, Warszawa 1966, s. 51. Por. A. Midro, Istota życia czlowieka z perspektywy lekarza genetyka, [w:] Otoczmy troska życie. Międzynarodowa Konferencja Naukowa $w$ Białymstoku $w$ dniach 25-26 pazdziernika 2013 roku, Białystok 2013, s. 11-18.

Cyt. za: G. Kuby, Gender-wspótczesna rewolucja antropologiczna, [w:] Otoczmy troskążycie, op. cit., s. 69.Zob. J.-Ph.Pierron, Éthique et sexualité. Herméneutique de l'être sexué et de ses imaginaires, „Revue de Théologie et de Philosophie”, 2007, vol. 139, nr 1, s. 49-64; K. Demmer, Die synthetische Biologie-Ende oder Wende der Naturrecht, „Freiburger Zeitschrift für Philosophie und Theologie”, 60(2013), H. 1, s. 166-178.

Por. G. Kuby, Gender - wspótczesna rewolucja antropologiczna, op. cit., s. 67-78; zob. także, J. Zabielski, Odpowiedzialność za życie, s. 11-53; J. Joblin, Identité chrétienne dans un monde global, multiculturel et pluraliste, „Gregorianum”, 93, 2(2012), s. 333-347; M. Zimmermann-Acklin, Rationalität, Narrativität und selbstreflexive Hermeneutik. Zum Profil einer theologischen Bioethik in pluralistischer Gesellschaft, „Freiburger Zeitschrift für Philosophie und Theologie”, 59(2012), nr 1, s. 223-233. 
- Stwórcy, który stworzył ludzi wyłącznie jako „mężczyznę i kobietę” ( $\mathrm{Rdz} 1,27)$.

Hermeneutyka

\section{Zakończenie}

Rozumność i wolność ludzkiej natury sprawiają, że działanie ludzkie ma charakter moralny. Wartościowanie ludzkich czynów domaga się ustalenia konkretnych norm moralnych, które pozwolą rozpoznać etyczną możliwość tych czynów oraz ocenić ich stan. Równość i stałość ludzkiej natury uświadamia, że wszyscy ludzie podlegają tym samym normom, które zakotwiczone są w naturalnym prawie, stanowiącym podstawę etyki uniwersalnej. Moc zobowiązująca tego prawa jest stała i powszechna, tak jak niezmienna jest ludzka natura, którą Bóg - Stwórca obdarował każdego człowieka, stwarzając go „na swój obraz” (Rdz 1,27). Wszyscy więc ludzie zobowiązani są postępować „po ludzku", czyli zachować normy zawarte w swym człowieczeństwie. Normy te zobowiązują też ludzi do stanowienia „ludzkiego prawa” jako zasad postępowania ludzkiej społeczności. Stanowione przez człowieka prawo winno jednak przede wszystkim zachować zgodność z prawem naturalnym, które jest wyrazem woli Boga. Rozumowanie to ukazuje wartość i godność człowieka oraz jego odpowiedzialność za podejmowane czyny.

Natura wszystkich istot została określona i zawiera się w granicach przez nas ustanowionych. [...] Nie uczyniłem cię ani istotą niebiańską, ani ziemską, ani śmiertelną, ani nieśmiertelną, abyś jako swobodny i godny siebie twórca i rzeźbiarz sam sobie nadał kształt, jaki zechcesz. Będziesz mógł degenerować się i staczać do rzędu zwierząt; i będziesz mógł odradzać się i mocą swojego ducha wznosić się do rzędu istot boskich $^{26}$.

Słowa kluczowe: natura, prawo naturalne, prawo stanowione, przemiany cywilizacyjno-kulturowe, wartościowanie etyczne, zobowiązania moralne, deformacja moralności, odpowiedzialność moralna.

\section{Bibliografia:}

1. Arystoteles, Polityka z dodaniem pseudo-arystotelesowskiej Ekonomii, Warszawa 1964.

2. Arystoteles, Polityka.

3. Bauman Z., Etyka ponowoczesna, Warszawa 1996.

$26 \quad$ G. Pico della Mirandola, De hominis dignitate, [w:] Filozofia wtoskiego odrodzenia, wybór i przekład A. Nowicki, Warszawa 1967, s. 139. 
4. Bocheński J., Zarys historii filozofii, Kraków 1993.

5. Chroust A. H., The Fundamental Ideas in St. Augustine Philosophy of Law, „The American Journal of Jurisprudence”, 1973, vol. 18.

6. Chyrowicz B., Bezcenna, ,informacja”. Uwagi na temat normatywnego statusu genomu ludzkiego, [w:] idem (red.), Granice ingerencji $w$ nature, Lublin 2001.

7. Demmer K., Die synthetische Biologie-Ende oder Wende der Naturrecht, „Freiburger Zeitschrift für Philosophie und Theologie”, 60(2013), H. 1.

8. Grocjusz H., Trzy księgi o prawie wojny i pokoju, w których znajduja wyjaśnienie prawo natury i prawo narodów, tłum. R. Bierzanek, Warszawa 1957.

9. Iribarne Ph. d', Conversion et résistance des cultures, „Christus. Accompagner l'homme en quête de Dieu", 2011, nr 229.

10. Joblin J., Identité chrétienne dans un monde global, multiculturel et pluraliste, „Gregorianum”, 93, 2(2012).

11. Kirste S., Der Beitrag des Rechts zum kulturellen Gedächtnis, „ARSP”, 2008, vol. 94, z. 1.

12. Kongregacja Nauki Wiary, Instrukcja Dignitas personae, Rzym 2008.

13. Kornatowski W., Społeczno-polityczna myśl św. Augustyna, Warszawa 1965.

14. Krąpiec M. A., Człowiek i prawo naturalne, Lublin 1999.

15. Kuby G., Gender - wspótczesna rewolucja antropologiczna, [w:] Otoczmy troska życie. Międzynarodowa Konferencja Naukowa w Biatymstoku $w$ dniach 25-26 października 2013 roku, Białystok 2013.

16. Midro A., Istota życia człowieka z perspektywy lekarza genetyka, [w:] Otoczmy troska życie. Międzynarodowa Konferencja Naukowa w Biatymstoku w dniach 25-26 października 2013 roku, Białystok 2013.

17. Międzynarodowa Komisja Teologiczna, W poszukiwaniu etyki uniwersalnej: Nowe spojrzenie na prawo naturalne, tłum. R. Kiełtyka, Warszawa 2010.

18. Olszewski H., Zmierczak M., Historia doktryn politycznych i prawnych, Poznań 1993.

19. Pico della Mirandola G., De hominis dignitate, [w:] Filozofia wtoskiego odrodzenia, wybór i przekład A. Nowicki, Warszawa 1967.

20. Piechowiak M., Prawo naturalne a prawa człowieka, [w:] A. Maryniarczyk, K. Stępień, P. Gądek (red.), Substancja, Natura, Prawo naturalne, Lublin 2006, s. 396-398.

21. Pierron J.-Ph.,. Éthique et sexualité. Herméneutique de l'être sexué et de ses imaginaires, „Revue de Théologie et de Philosophie”, 2007, vol. 139, nr 1.

22. Reale G., Historia filozofii starożytnej, t. 1, Lublin 2008.

23. Schnebel K. B., Individuelles und Kollektiv ausgeübtes Menschenrecht als Selbstbestimmungsrecht, „ARSP”, 2008, vol. 94, z. 1.

24. Schockenhoff E., Naturrecht und Menschenwürde. Universale Ethik in einer geschichtlichen Welt, Mainz 1996.

25. Ślipko T., Pojęcie człowieka w świetle wspótczesnejfilozoficznej antropologii marksistowskiej w Polsce, ,Zeszyty Naukowe KUL”, 1967, nr 2.

26. Thomae Aquinatis, Summa contra Gentiles.

27. Thomae Aquinatis, Summa theologiae.

28. Tokarczyk R., Klasycy praw natury, Lublin 1988. 
29. Varaut J.-M., Możliwe, lecz zakazane. O powinności prawa, tłum. S. Szwabski, Warszawa 1966.

30. Wallis M., Koncepcje biologiczne w humanistyce, [w:] Fragmenty filozoficzne, III. Księga Pamiątkowa ku czci Profesora Tadeusza Kotarbińskiego w 80. rocznice urodzin, Warszawa 1967.

31. Wojcieszek K., Relacyjna identyfikacja człowieczeństwa embrionu, „Colloquia Communia", 2005, nr 1-2.

32. Zabielski J., Fertilisierung In Vitro. Die Sicht der Kirche, [w:] A. Laun, A. Marcol (red.), Ethisch relevante Techniken der Biologen, Opole 2003.

33. Zabielski J., Odpowiedzialność za życie, Białystok 2007.

34. Zabielski J., Sztuczna prokreacja jako destrukcja osobowej godności człowieka, [w:] T. Reroń (red.), Świętość ludzkiego życia. Wokót Instrukcji „Dignitas personae”, Wrocław 2009.

35. Zimmermann-Acklin M., Rationalität, Narrativität und selbstreflexive Hermeneutik. Zum Profil einer theologischen Bioethik in pluralistischer Gesellschaft, „Freiburger Zeitschrift für Philosophie und Theologie”, 59(2012), nr 1. 